http://doi.org/10.35784/iapgos.896

\title{
TECHNOLOGY AND MEASUREMENTS OF MAGNETORESISTANCE IN THIN-LAYERED FERROMAGNETIC STRUCTURES
}

\author{
Jakub Kisała ${ }^{1}$, Karolina Czarnacka ${ }^{2}$, Mateusz Gęca ${ }^{1}$, Andrzej Kociubiński ${ }^{1}$ \\ ${ }^{1}$ Lublin University of Technology, Lublin, Poland, ${ }^{2}$ University of Life Sciences, Lublin, Poland \\ Abstract. The paper presents the technology for obtaining NiFe/Ti/NiFe layer structures in MEMS technology using magnetron purge with the assumption \\ of being used as semi-magnetic sensors. A series of samples was made on a glass substrate with a sandwich structure, where the individual layers were \\ $100 \mathrm{~nm} \mathrm{NiFe,} 10 \mathrm{~nm}$ Ti and on top again NiFe with a thickness of $100 \mathrm{~nm}$. Measurements of DC resistance of the obtained structures in a constant \\ magnetic field, which was produced by neodymium magnets and an electromagnet, were carried out. The obtained results confirm the occurrence of \\ phenomena known as the magnetoresistance effect. The influence of the spatial arrangement of structures relative to the constant magnetic field vector was \\ checked and proved.
}

Keywords: static magnetic field, magnetron sputtering, MEMS, magnetoresistance

\section{TECHNOLOGIA I POMIARY MAGNETOOPORU W CIENKOWARSTWOWYCH STRUKTURACH FERROMAGNETYCZNYCH}

Streszczenie. W pracy przedstawiono technologię otrzymywania struktur warstwowych NiFe/Ti/NiFe w technologii MEMS metoda rozpylania magnetronowego $w$ założeniu mających stużyć jako czujniki pót magnetycznych. Wykonano serię próbek na szklanym podłożu o budowie kanapkowej, gdzie poszczególne warstwy stanowity $100 \mathrm{~nm}$ NiFe,10 nm Ti oraz na wierzchu ponownie NiFe o grubości 100 nm. Przeprowadzono pomiary rezystancji stałoprądowej otrzymanych struktur $w$ stałym polu magnetycznym, które byto wytwarzane przez magnesy neodymowe oraz elektromagnes. Otrzymane wyniki potwierdzaja występowanie zjawisk określanych jako efekt magnetooporowy. Sprawdzony oraz udowodniony został wpływ ułożenia przestrzennego struktur względem wektora stałego pola magnetycznego.

Słowa kluczowe: statyczne pole magnetyczne, rozpylanie magnetronowe, MEMS, magnetoopór

\section{Introduction}

The phenomenon of magnetoresistance is defined as the change in the resistance of a material or device under the influence of a magnetic field [4]. One of the first applications of devices operating based on this effect were magnetic field sensors and hard disk read heads [5]. Currently, magnetoresistive sensors are widely used in many industries due to the low production cost, temperature stability, simplicity of implementation and the possibility of integration with CMOS systems $[12,19]$. One of the most popular applications of this type of sensors is their use for current measurement, because they ensure high sensitivity and linearity of measurements without interfering with the integrity of the measured circuit [4]. In the automotive industry, magnetoresistive sensors are used to measure distance, angle, speed and rotational speed due to the convenience of their use in contactless position registration [4]. They are also used in the biotechnology industry, where they are used, among others in tests for proteins and microfluidic systems $[9,11]$.

Besides widely used sensors working based on the Hall effect, an attractive option for determining the intensity of the magnetic field seems to be microscopic structures whose work is based on the phenomenon of magnetoresistance. Their advantages are low weight and dimensions, high sensitivity and stability $[1,2,13]$. A good example of the material for the production of such structures is the NiFe alloy, which is used in the vast majority of sensors working on the principle of magnetoresistance [21, 22]. It is a popular material used in spintronics due to the appropriate magnetic parameters and is characterized by sufficiently large magnetoresistance changes [22]. However, the use of layered structures significantly increases the intensity of magnetoresistive phenomena [1,2]. A simple three-layer structure consisting of two external ferromagnetic layers and an internal diamagnetic or paramagnetic layer, with a much higher conductivity, provides large changes in resistance under the influence of a constant magnetic field. As ferromagnetic layers, NiFe alloy [20] or pure metals such as cobalt or iron [14] are usually used, because they have low magnetostriction and are magnetically soft. As an internal nonmagnetic layer, precious metals or copper are used, which ensures good electrical conductivity $[8,16]$. In such systems, several parameters can be manipulated, for example, layer thickness, surface roughness, and even crystal structure, which can strongly affect the magnetic properties of the product [6].
A wide spectrum of deposition techniques appear in the process of obtaining ferromagnetic layered structures, which include spin coating, chemical vapor deposition (CVD), ion sputtering, vacuum deposition, or pulse electroplating $[3,7,10]$. It is worth emphasizing that the spin coating method cannot guarantee a uniform coating thickness [15], and the layers obtained by CVD methods have low purity [18]. On the other hand, thin ferromagnetic layers produced by means of vacuum deposition can be coarse-grained, in the range of $200-500 \mathrm{~nm}$, which negatively affects the magnetic properties. Therefore, ion sputtering is a method that is often used, which ensures even coverage and high sample purity [17].

The purpose of the work was to develop a technology for the production of MEMS $\mathrm{NiFe} / \mathrm{Ti} / \mathrm{NiFe}$ structures and to conduct measurements of DC resistance depending on the magnetic field in terms of determining the occurrence of the phenomenon of magnetoresistance.

\section{Technology of thin-film resistor}

Designed structures were developed in the Department of Electronics and Information Technology of Lublin University of Technology using magnetron sputtering. A Kurt J. Lesker Company ${ }^{\circledR}$ NANO 36 sputtering system was used to develop thin film layers. Microscope slides were used as substrates for structures.

Figure 1. shows the sequence of technological steps performed to develop designed structures. The first and the third layer of the device were deposited using a $\mathrm{NiFeCuMo}$ alloy target. Due to a low content of copper and molybdenum in the alloy, it will be further on referred to as $\mathrm{NiFe}$.

Process parameters for a $100 \mathrm{~nm}$ thick NiFe layer deposition in a vacuum of $10^{-7}$ Torr were as follows: plasma power density $180 \mathrm{~W} / \mathrm{cm}^{-2}$, argon flow rate $-100 \mathrm{sccm}$, deposition rate $-0.3 \AA / \mathrm{s}$, deposition time - $57 \mathrm{~min}$. In the next step, a $10 \mathrm{~nm}$ thick layer of titanium was deposited. Purity of a used target was equal to $98.4 \%$. Process parameters in a vacuum of $10^{-7}$ Torr were: plasma power density $-80 \mathrm{~W} / \mathrm{cm}^{-2}$, argon flow rate $-100 \mathrm{sccm}$, deposition rate $-0.1 \AA / \mathrm{s}$, deposition time - approx $15 \mathrm{~min}$.

Following the deposition of a second layer, at both ends of developed structures, electrical contacts to titanium layer with dimensions of $1 \times 1 \mathrm{~mm}^{2}$ were provided using kapton tape as a mask. 
The second layer of NiFe was deposited with the same process parameters as previously mentioned. Finally, copper wires were glued to electrical contacts using Anders Products Wire Glue. The resulting structures have dimensions of $10 \mathrm{~mm} \times 1 \mathrm{~mm} \times 210 \mathrm{~nm}$. a)

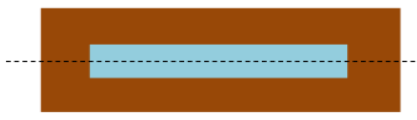

b)

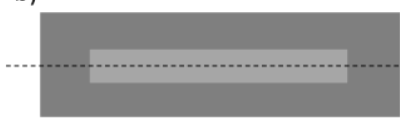

c)

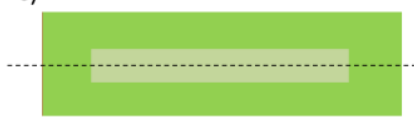

d)

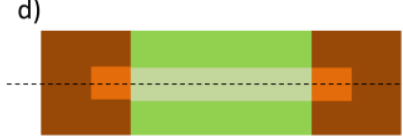

e)

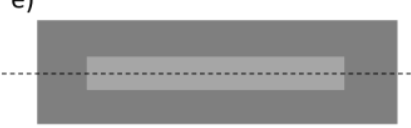

f)

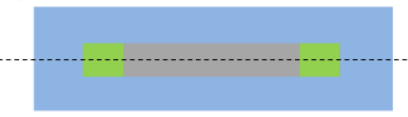

g)

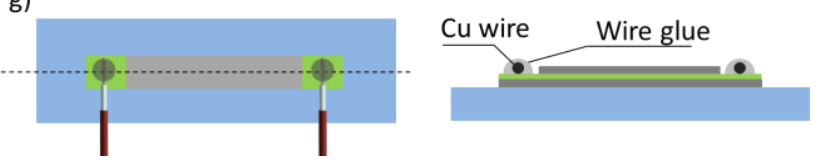

Fig. 1. The fabrication steps of the ferromagnetic resistor process: (a) sticking a kapton tape with exposed space for the structure, (b) deposition of a $100 \mathrm{~nm} \mathrm{NiFe}$ layer, (c) deposition of a $10 \mathrm{~nm}$ Ti layer, (d) covering titanium contact fields with a kapton tape, (e) deposition of a second $100 \mathrm{~nm}$ NiFe layer, (f) removal of the kapton tape, $(g)$ the final device.

\section{Experimental procedure}

The research carried out on the prepared $\mathrm{NiFe} / \mathrm{Ti} / \mathrm{NiFe}$ structure was aimed to confirming the occurrence of magnetoresistance effects. First, a pair of neodymium magnets mounted in a vice were used as the source of the permament magnetic field. The measurements of the constant current of the sample were carried out using a KeySight 34410A multimeter cooperating with LabView software, where the measurement values were stored. The measurements were carried out for three positions of the sample relative to the magnetic field as shown schematically in figure 2 . The value of magnetic flux density between neodymium magnets was about $0.5 \mathrm{~T}$. The intervals between individual measurements were 5 seconds.

The next stage was measurements carried out in a magnetic field created by an electromagnet whose coil was connected to a DC power supply. A schematic of the measuring system for this configuration is shown in figure 3 .

The structure resistance values were measured for the increasing magnetic flux density value, which was obtained by stepwise changing the voltage value applied to the coil from $0 \mathrm{~V}$ to $400 \mathrm{~V}$, with a $10 \mathrm{~V}$ step, for two variants of voltage coil polarization. Changes in voltage directly affected into changes in the coil current, and thus the value of magnetic flux density. This values were measured using a GM08 teslometer from Hirst Magnetics and the characteristics of the magnetic flux density $B$ depended on the coil current $I$ was developed, Fig. 4.

The number of resistance measurements for each value of the magnetic flux density was 100 , between changes in the magnetic flux density was 5 seconds gap in the resistance measurement. The value of sample resistance for a given coil current was statistically developed from 100 measurements. The measurements were carried out in three positions of the sample in the magnetic field as shown in figure 2.

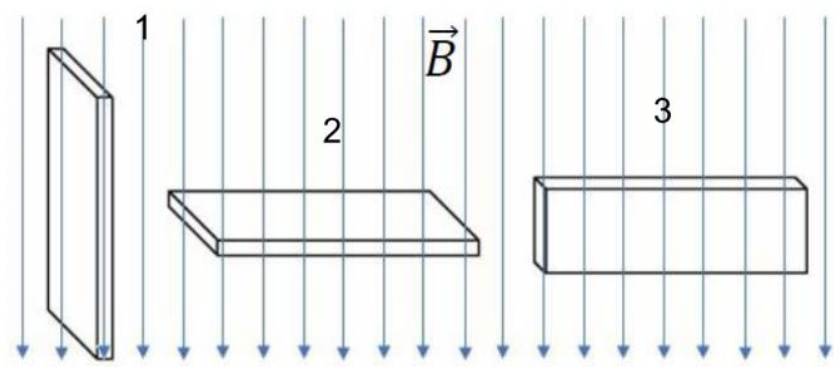

Fig. 2. Positions of the sample in the magnetic field

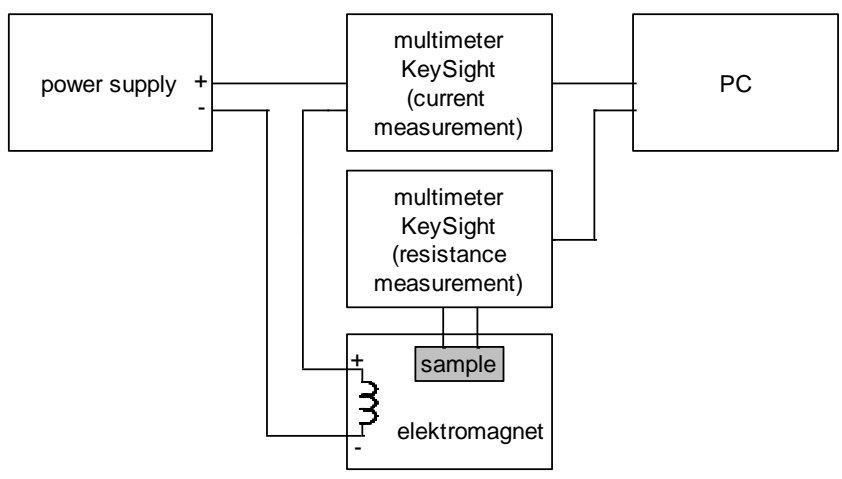

Fig. 3. The scheme of measurement station

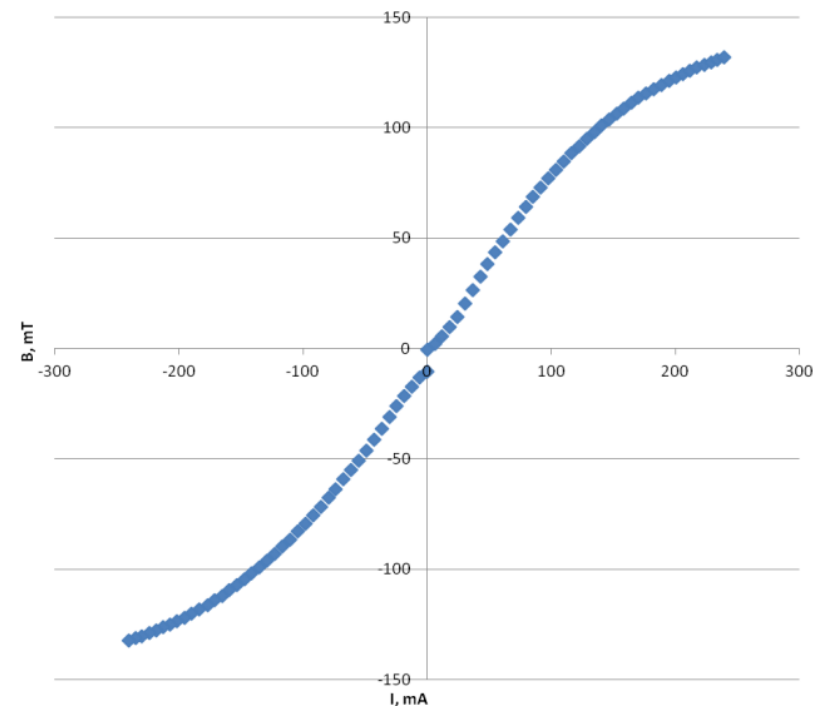

Fig. 4. Electromagnet characteristics

\section{Results and discussion}

Measurements of a change in resistance of the tested $\mathrm{NiFe} / \mathrm{Ti} / \mathrm{NiFe}$ sample under the influence of a static magnetic field with a flux density of approximately $0.5 \mathrm{~T}$ show evident changes in sample's resistance, as shown in figure 5. In both cases, the sample's resistance decreases when placed in the magnetic field and returns to its initial value after removing it from neodymium magnets. For the position 2, a resistance change of approximately $0.5 \Omega$ is visible, while for the position $1-$ approx. $1 \Omega$. Small fluctuations in the resistance value of about $0.2 \Omega$ do not seem to affect its change resulting from magnetoresistive properties.

Further measurements verifying presence of the magnetoresistance phenomenon in the designed structures were conducted using an electromagnet providing magnetic flux densities of significantly smaller magnitude (approx. 0.13 T) (Fig. 6). 


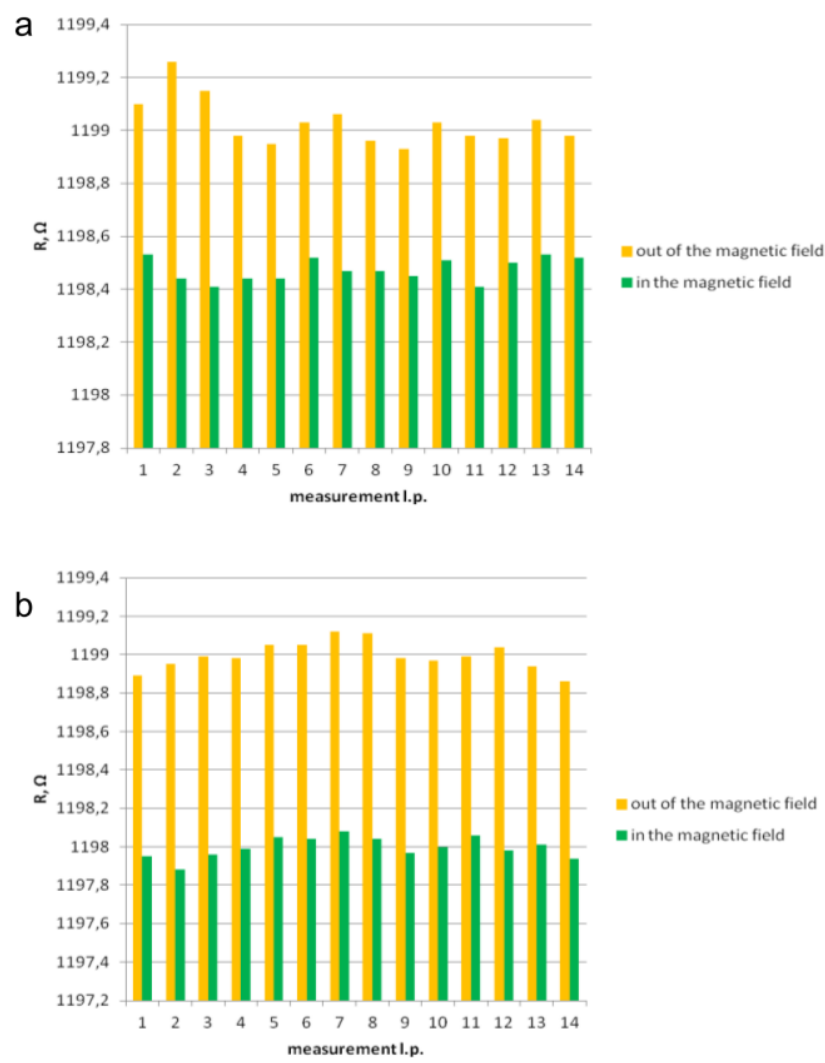

Fig. 5. Measurements of resistance in the magnetic field of a neodymium magnet in the position: a) 2, b) 1

For a sample in position 2 , it is difficult to clearly state the nature of the changes; the sample's resistance values in and outside the field do not differ significantly from each other. Position 1 of the structure gives the expected results. Changes in resistance induced by a presence of a magnetic field are clearly visible and reach value of approx. 0.6 $\Omega$. As in previous cases, fluctuations in resistance during measurements do not seem to significantly affect the differences in structure's resistance in and outside of the magnetic field.

a

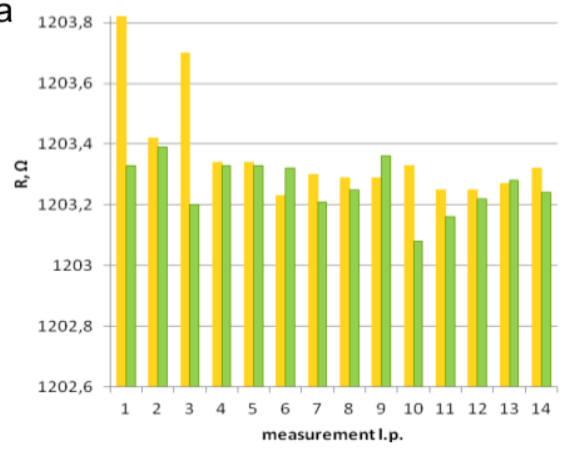

in out of the megnetic field an the magnetic field

$\mathrm{b}$

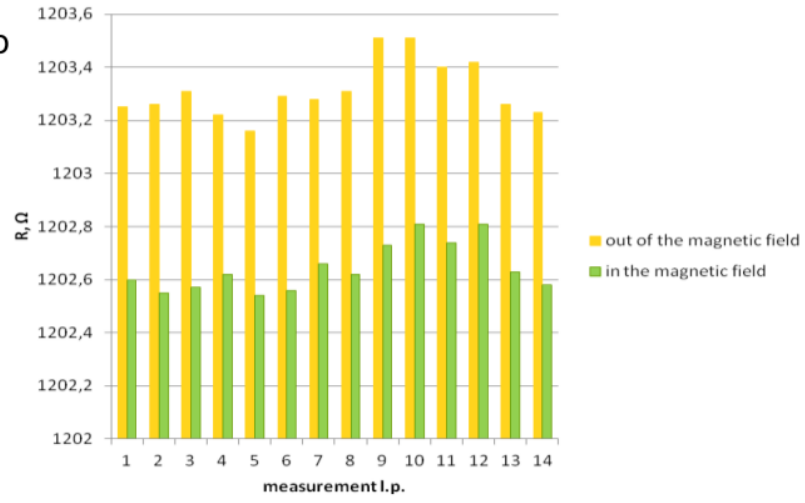

Fig. 6. Measurements of resistance in the magnetic field of the electromagnet in position: a) 2, b) 1
The first series of measurements was conducted for the position 1 of the $\mathrm{NiFe} / \mathrm{Ti} / \mathrm{NiFe}$ structure. Obtained results are presented in figure 5. Further experiments were run for the structures positions 2 and 1 , as presented in figures 7 and 8 respectively. The difference between an initial resistance of a sample for the current of the solenoid coil equal to $0 \mathrm{~A}$ and the sample's resistance measured at a given solenoid coil's current is denoted as $\Delta \mathrm{R}$.

For all structure arrangements, a decrease in resistance due to an increase in magnetic flux density is observed. The smallest difference in resistance $\Delta \mathrm{R}$ between extreme values of the magnetic flux density for a given polarization occurs in the case of a position 2 of the sample and is about $-0.6 \Omega$. The largest difference in resistance $\Delta \mathrm{R}$ reaches approx. $-1.4 \Omega$. For a structure in position 2, relatively large differences between adjacent measurement points are visible. In the position 3 , where the $\Delta R$ value is more than twice as large compared to other sample's arrangements, $\Delta \mathrm{R}$ fluctuations are also less noticeable. The magnetoresistance effect is clearly visible and its intensity depends on the arrangement of the structure relative to the direction of the magnetic field vector. Despite the differences in the characteristics determined for both current polarities, it can be stated that the effect of magnetic resistance occurs regardless of the sense of the magnetic field vector.

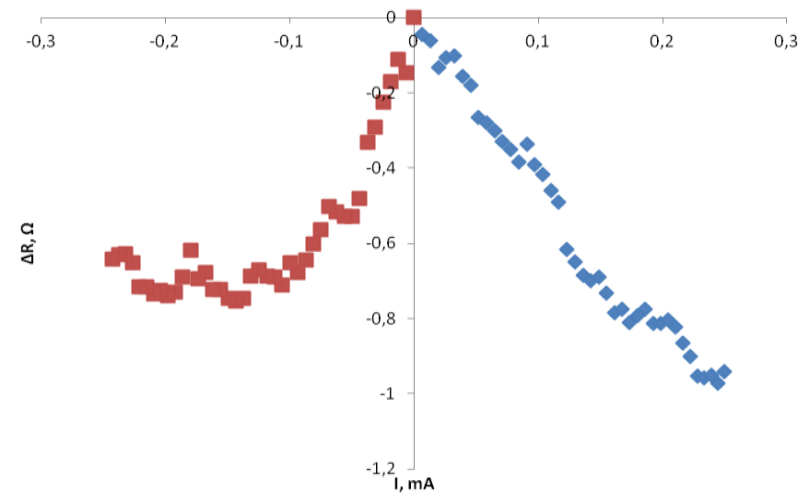

Fig. 7. The decrease in resistance depending on the magnetic flux density (the diagram shows as the coil current) - position 1

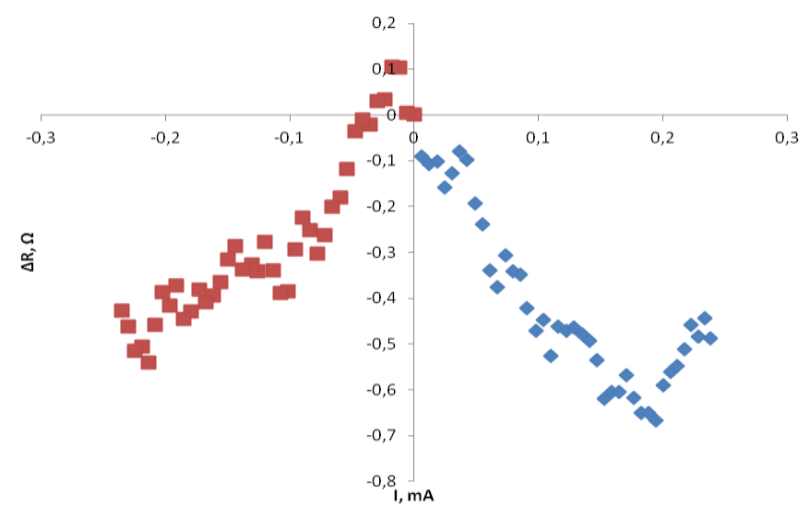

Fig. 8. The decrease in resistance depending on the magnetic flux density (the diagram shows as the coil current) - position 2

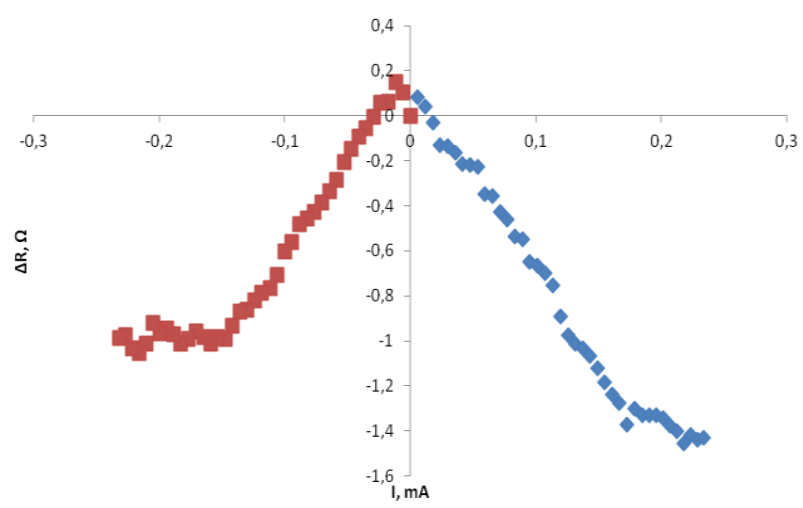

Fig. 9. The decrease in resistance depending on the magnetic flux density (the diagram shows as the coil current) - position 3 


\section{Conclusion}

The measurements of the resistance of the obtained $\mathrm{NiFe} / \mathrm{Ti} / \mathrm{NiFe}$ structures confirm the assumptions about the presence of magneto-resistance effects in them. Structure production technology therefore brings the expected results. The studied effect of the spatial arrangement of the sample relative to the magnetic field allows to determine its impact on the intensity of magnetoresistive phenomena occurring.

\section{References}

[1] Chen L., Zhou Y., Lei C., Zhou Z. M., Ding W.: Giant magnetoimpedance effect in sputtered single layered $\mathrm{NiFe}$ film and meander $\mathrm{NiFe} / \mathrm{Cu} / \mathrm{NiFe}$ film. Journal of Magnetism and Magnetic Materials 322(19)/2010, 2834-2839, [http://doi.org/10.1016/j.jmmm.2010.04.038]

[2] Chen L., Zhou Y., Lei C., Zhou Z. M.: Effect of sputtering parameters and sample size on giant magnetoimpedance effect in $\mathrm{NiFe}$ and $\mathrm{NiFe} / \mathrm{Cu} / \mathrm{NiFe}$ films. Materials Science and Engineering B: Solid-State Materials for Advanced Technology 172(2)/2010, 101-107, [http://doi.org/10.1016/j.mseb.2010.04.026]

[3] Dixit G., Singh J. P., Srivastava R. C., Agrawal H. M., Choudhary R. J., Ajay G.: Structural and magnetic behaviour of $\mathrm{NiFe}_{2} \mathrm{O}_{4}$ thin film grown by pulsed laser deposition. Indian Journal of Pure \& Applied Physics 48(4)/2010, 287-291.

[4] Djamal M., Ramli: Development of sensors based on giant magnetoresistance material. Procedia Engineering 32/2012, 60-68, [http://doi.org/10.1016/j.proeng.2012.01.1237].

[5] Ennen I. Kappe D., Rempel T, Glenske C., Hütten A. Giant Magnetoresistance: Basic concepts, microstructure, magnetic interactions and applications. Sensors 16/2016, [http://doi.org/10.3390/s16060904].

[6] Esmaili S., Bahrololoom M. E., Zamani C.: Electrodeposition of $\mathrm{NiFe} / \mathrm{Cu}$ multilayers from a single bath. Surface Engineering and Applied Electrochemistry 47(2)/2011, 107-111, [http://doi.org/10.3103/S1068375511020049].

[7] Fernandez G. V., Grundy P. J., Vopson M. M.: Control and Analysis of Grain Size in Sputtered NiFe Thin Films. Journal of Condensed Matter Physics $1(1) / 2013,6-9$

[8] García-Arribas A., Fernández E., Svalov A., Kurlyandskaya G. V., Barandiaran J. M.: Thin-film magneto-impedance structures with very large sensitivity. Journal of Magnetism and Magnetic Materials 400/2016, 321-326, [http://doi.org/10.1016/j.jmmm.2015.07.107]

[9] Gijs M. A. M. Magnetic bead handling on-chip: New opportunities for analytical applications. Microfluidics and Nanofluidics 1/2004, 22-40, [http://doi.org/10.1007/s10404-004-0010-y].

Eng. Jakub Kisala
e-mail: jakub.kisala @ pollub.edu.pl
Master student at the Lublin University of Technology
Faculty Electrical Engineering and Computer Science
Branch of study: Mechatronics
Speciality: Mobile system in mechatronics

\section{Sc. Eng. Karolina Czarnacka}

e-mail: karolina.czarnacka@up.lublin.pl

An employee as an assistant in the Department of Fundamentals of Technology at the University of Life Sciences in Lublin. Ph.D. student at the Lublin University of Technology in the discipline of Electrical Engineering.

[10] Gupta N., Verma A., Kashyap S. C., Dube D. C.: Dielectric behavior of spindeposited nanocrystalline nickel-zinc ferrite thin films processed by citrateroute. Solid State Communications 134(10)/2005, 689-694, [http://doi.org/10.1016/j.ssc.2005.02.037].

[11] Hall D. A., Gaster R. S., Lin T., Osterfeld S. J., Han S., Murmann B., Wang S. X.: GMR biosensor arrays: A system perspective. Biosensors and Bioelectronic 25(9)/2010, 2051-2057, [http://doi.org/10.1016/j.bios.2010.01.038].

[12] Jogschies L., Klaas D., Kruppe R., Rittinger J., Taptimthong P., Wienecke A., Wurz M. C.: Recent developments of magnetoresistive sensors for industrial $\begin{array}{lll}\text { applications. } & \text { Sensors } & \text { 28665-28689 }\end{array}$ [http://doi.org/10.3390/s151128665].

[13] Kurlyandskaya G. V., Fernández E., Svalov A., Burgoa Beitia A., GarcíaArribas A., Larranaga A.: Flexible thin film magnetoimpedance sensors. Journal of Magnetism and Magnetic Materials 415/2016, 91-96, [http://doi.org/10.1016/j.jmmm.2016.02.004].

[14] Kuru H., Kockar H., Alper M. Giant magnetoresistance (GMR) behavior of electrodeposited $\mathrm{NiFe} / \mathrm{Cu}$ multilayers: Dependence of non-magnetic and magnetic layer thicknesses. Journal of Magnetism and Magnetic Materials 444/2017, 132-139, [http://doi.org/10.1016/j.jmmm.2017.08.019].

[15] Lai C. H., Matsuyama H., White R. L., Anthony T. C., Matsuyama H. Anisotropic Exchange for NiFe Films Grown on Epitaxial NiO. IEEE Transactions on Magnetics 31(6)/1995, 2609-2611, [http://doi.org/10.1109/20.490068].

[16] Makhnovskiy D. P., Panina L. V., Fry N., Mapps D. J.: Magneto-impedance in $\mathrm{NiFe} / \mathrm{Au} / \mathrm{NiFe}$ sandwich films with different types of anisotropy. Journal of Magnetism and Magnetic Materials 272-276(III)/2004, 1866-1867, [http://doi.org/10.1016/j.jmmm.2003.12.833].

[17] Motomura Y., Tatsumi T., Urai H., Aoyama M.: Soft Magnetic Properties and Heat Stability for $\mathrm{Fe} / \mathrm{NiFe}$ Superlattices. IEEE Transactions on Magnetics 26(5)/1990, 2327-2331, [http://doi.org/10.1109/20.104714].

[18] Phani A. R., Santucci S.: Structural characterization of nickel titanium oxide synthesized by sol-gel spin coating technique. Thin Solid Films 396/2001, 1-4, [http://doi.org/10.1016/S0040-6090(01)01131-2].

[19] Reig C., Cubells-Beltrán M.-D., Ramírez Munoz D.: Magnetic Field Sensors Based on Giant Magnetoresistance (GMR) Technology: Applications in Electrical Current Sensing. Sensors 9(10)/2009, 7919-7942, [http://doi.org/10.3390/s91007919].

[20] Svalov A. V., Larranaga A., Kurlyandskaya G. V.: Effect of Ti seed and spacer layers on structure and magnetic properties of $\mathrm{FeNi}$ thin films and FeNi-based multilayers. Materials Science and Engineering B: SolidState Materials for Advanced Technology 188/2014, 102-105, [http://doi.org/10.1016/j.mseb.2014.06.006]

[21] Zhao C. J., Wu Z L, Zhao Z D., Ding L, Lu X, A, Li X, J., Yu G. H. Influence on the transport behaviors of spin-polarized electrons exerted by $\mathrm{MgO} / \mathrm{NiFe}$ and $\mathrm{NiFe} / \mathrm{MgO}$ heterointerfaces. Journal of Magnetism and Magnetic Materials 368/2014, 59-63, [http://doi.org/10.1016/j.jmmm.2014.05.013].

[22] Zhao Z. D., Li M. H., Zhao C. J., Yang G., Zhang J. Y., Jiang S. L., Yu G. H. Large enhancement of magnetoresistance in NiFe film with $\mathrm{MgO}$ layers sandwiched after annealing. Applied Surface Science 321/2014, 554-559, [http://doi.org/10.1016/j.apsusc.2014.10.047].

\begin{abstract}
M. Sc. Eng. Mateusz Gęca
e-mail: mati.geca@gmail.com

An employee in the Department of Electronics and Information Technology, Lublin University of Technology (LUT). He received the M.Sc. degree in mechatronics from LUT. Research area concerns diagnostics and characterization of semiconducto devices.
\end{abstract}

http://orcid.org/0000-0002-0519-7389

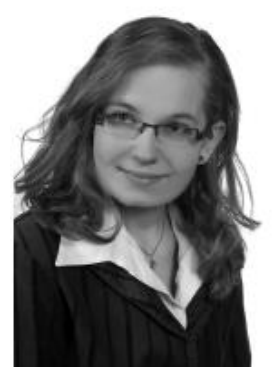

\section{Ph.D. Andrzej Kociubińsk}

e-mail: akociub@semiconductor.pl

He received the M.Sc. and Ph.D degrees in electronic engineering from Warsaw University of Technology, Poland. In 2007 he joined the Lublin University of Technology, where he was involved in research on semiconductor technology. His research interest is concentrated on semiconductor devices an technology. His recent activities are related to microsystems for biomedical applications. 